\title{
Assessment on the growth performance of planted Dryobalanops beccarii at reforestation sites after implementation of selective girdling
}

\author{
MOHD EFFENDI WASLI`, DOUGLAS BUNGAN AMBUN, MEEKIONG KALU, MOGERET SIDI, \\ HAFSAH NAHRAWI, HASHIMAH ELIAS \\ Department of Plant Science and Environmental Ecology, Faculty of Resource Science and Technology, Universiti Malaysia Sarawak. 94300 Kota \\ Samarahan, Sarawak, Malaysia
}

Manuscript received: 14 January 2020. Revision accepted: 9 April 2020.

\begin{abstract}
Wasli ME, Ambun DB, Kalu M, Sidi M, Nahrawi H, Elias H. 2020. Assessment on the growth performance of planted Dryobalanops beccarii at reforestation sites after implementation of selective girdling. Biodiversitas 21: 1880-1889. This study was conducted to evaluate the growth performance of planted Dryobalanops beccarii Dyer at reforestation sites after silvicultural practices in Gunung Apeng National Park (GANP), Sarawak. The assessed area was planted with D. beccarii in 2005 and undergo silvicultural treatment by understory clearing which implemented annually. Due to the suppressed growth rate of the planted trees, an additional silvicultural treatment, the selective girdling on selected pioneer species, was implemented once, in 2012. In this study, study plots with two treatments were established: T1: understory clearing only (control plot), and T2: additional selective girdling of existing pioneer species in addition to the understory clearing practice applied in T1. The growth performance of the planted D. beccarii in terms of $\mathrm{DBH}$, height, survival and mean annual increments in diameter (MaiD) and height (MaiH) were assessed and monitored at the initial stage when the selective girdling treatment was applied and 4, 24, 36, 48, 60 and 72 months after girdling. Our findings showed that the survival rates of planted trees at 72 months under treatments $\mathrm{T} 1$ and T2 were $82.9 \%$ and $79.2 \%$, respectively. The average tree DBH in T2 was significantly higher than that in T1, and the average tree DBH values for T1 and T2 were $7.5 \mathrm{~cm}$ and $9.4 \mathrm{~cm}$, respectively. The average tree heights for T1 and T2 were $8.3 \mathrm{~m}$ and $9.2 \mathrm{~m}$, respectively. In terms of the mean annual increments in height (MaiH) and diameter (MaiD), those in T2 were significantly higher than those in T1. Our findings indicated that T2 started to show better growth performance than $\mathrm{T} 1$ after a period of 36 months. In conclusion, the additional silvicultural treatment by selective girdling at the reforestation site had a long-term, progressive effect on the growth performance of the planted trees.
\end{abstract}

Keywords: Dryobalanops beccarii, growth performance, reforestation, selective girdling

\section{INTRODUCTION}

The loss of forests in Borneo has reached an alarming rate; an estimated 16.8 million ha of forest loss was reported from 1973-2010, and these losses were mainly due to extensive forest clearance to obtain forest products (Gaveau et al. 2014). This led to the destruction of habitat for flora and fauna and inevitably resulted in the loss of important medicinal plants and various climax tree species. Thus, reforesting the areas affected by these activities is essential for restoring the forest. Meanwhile, to ensure the success of the reforestation program, proper methods and techniques should be applied, such as the implementation of enrichment planting and suitable silvicultural practices. Enrichment planting is one of the methods used in attempts to supplement natural regeneration and improve the low tree growth performance observed in natural succession (Chai and Udarbe 1977; Appanah and Weinland 1993). Examples of enrichment planting, such as artificial gaps created by human intervention intended to reduce aboveground vegetation (Wyat-Smith 1963; Ådjers et al. 1995), reduce the competition between the planted tree and the adjacent bushes and shrubs. These practices can also be used to rehabilitate logged-over areas in tropical rainforests by using indigenous tree species; the process involves planting nursery-raised seedlings along a cleared line or in gaps that have been created naturally or artificially (WyatSmith 1963). In addition, Kammesheidt et al. (2003) investigated the irregular growth pattern of dipterocarps in response to competition and silviculture treatment in the lowland Mixed Dipterocarp Forest in Sarawak.

Silvicultural treatments have been widely used in logged forests to restore forests to their original conditions, or as close to the original conditions as possible (Villages et al. 2009). Many treatments can be applied, such as thinning, pruning, fertilizers, girdling, felling and others. The main purpose of applying these silvicultural methods is to control and manage the forest in a desirable manner by controlling forest change, accelerating change and maintaining the condition of the tree stands (Nyland 1996). Hence, better results can be obtained from reforestation efforts when the silvicultural treatments enhance the tree growth performance so that it is faster than that in forests without silvicultural intervention (Oliver 1992). Colin et al. (2018) reported that silvicultural practices are preferred for forest restoration purposes because they allow the direct manipulation of stand composition and structure. Even though the use of enrichment practices in forest plantations and in forest reserves has been reported (Romell 2007), making conclusions about the effects of various silvicultural treatments and the optimal conditions for enrichment planting is difficult due to the variability in 
natural forests and their dynamics. Moreover, there are knowledge gaps about enrichment planting and secondary forests as well as the performance of the planted tree species (Ramos and del Amo 1992; Ådjers et al. 1995; Kammesheidt 2002). In addition, numerous silviculture measures such as thinning, planting gaps and block planting have been proposed to improve forest management (Graaf 1986; Lamprecht 1989; Fredericksen and Mostacedo 2000; Fredericksen and Putz 2003), but such management practices aim to ensure future timber yields in the context of forest plantations (Jackson et al. 2002).

In this study, we introduced a silvicultural approach to maintain the forest structure and protect its ecological functions. Several studies have been performed on reforestation activities with indigenous tree species using various planting techniques to rehabilitate degraded land areas (McNamara et al. 2006; Hattori et al. 2013; Perumal et al. 2017; Jaffar et al. 2018). Thus, planting the original indigenous species to rejuvenate a specific forest area is essential, as these species can thrive better in the surrounding environment. Dryobalanops beccarii was planted to rejuvenate the forest ecosystem in Gunung Apeng National Park (GANP) after anthropogenic events (logging and forest clearance for agricultural purposes) in the area as this tree species indigenously grow on the hill (Ashton 2004). The implementation of selective girdling along with reforestation efforts is important. As Wasli et al. (2014) described in their preliminary assessment of the growth performance of planted trees under forest rehabilitation, proper silvicultural practices along a line planting system can potentially reduce competition between the dominant pioneer trees and the planted $D$. beccarii. Considering this finding, the specific objective of this study is to determine the effectiveness of additional silvicultural treatment, selective girdling, on the growth performance of planted $D$. beccarii in GANP.

\section{MATERIALS AND METHODS}

\section{Study site}

This study was conducted at the Gunung Apeng National Park (GANP), Serian Division, Sarawak, Malaysia (N00'55'24.7', E110³8'32.2' '). This region has a humid tropical climate with an average annual rainfall of 3500 $\mathrm{mm}$ and an annual temperature ranging from 23 to $33^{\circ} \mathrm{C}$ (Wasli et al. 2014). The size of the national park is estimated to be 1174 ha (Forest Department Sarawak 2009). GANP is located in an area of lowland hills with relatively steep slopes with elevation range from $60 \mathrm{~m}$ to $120 \mathrm{~m}$ above sea level with slope range $5^{\circ}$ to $30^{\circ}$. The area was previously logged over and has a history of shifting cultivation by local farmers (Lee 2013). The establishment of and was initiated by cooperation among the Forest Department and Sarawak and Japanese NGOs with the support of the Japan-Malaysia Association. For reforestation purposes, various tree seedlings were planted using the line planting technique, with lines cut $5 \mathrm{~m}$ apart and trees planted at $5 \mathrm{~m}$ intervals along the lines. In addition, the width of the planting line was $3 \mathrm{~m}$.

\section{Experimental design and silvicultural treatments}

In this study, the tree stand was planted in 2005 and accompanied by understory clearing practices. Silvicultural treatment, specifically selective girdling, was only applied in 2012 to improve the low survival rate and slow growth of the planted trees. The soil type at the study site from soil survey conducted was determined as grey-white podzolic soil, which has a prominent sandy texture with strong acidity, low nutrient contents, low moisture, and good aeration. Two study plots of $30 \mathrm{~m} \times 50 \mathrm{~m}$ were established within the area planted with $D$. beccarii in 2005. Two types of silvicultural treatment were implemented: T1: understory clearing only, which acted as a control plot, and T2: understory clearing with additional selective girdling practices on the existing pioneer species between or on the planting lines.
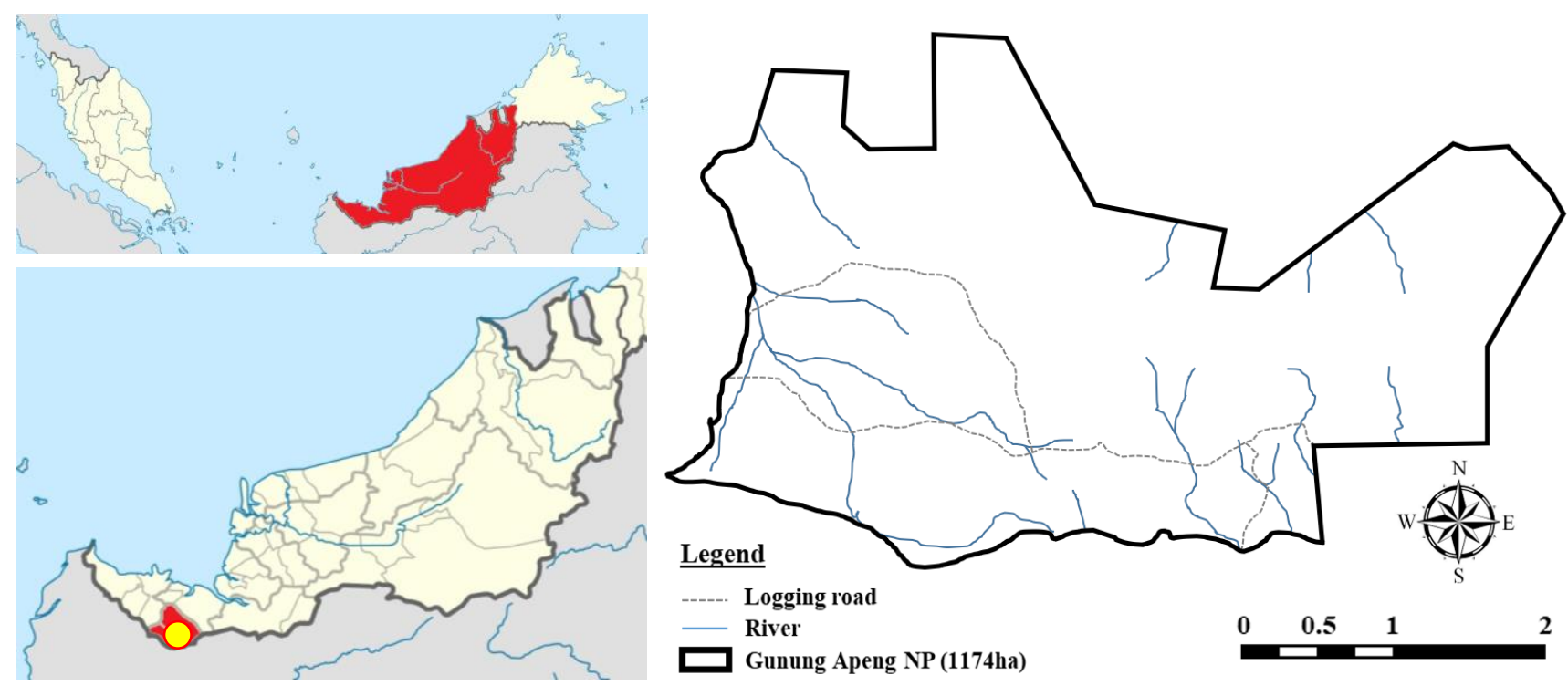

Figure 1. Location of Gunung Apeng National Park, Serian Division, Sarawak, Malaysia 
Table 1. Silvicultural treatments applied in areas planted with Dryobalanops beccarii (DB05) starting in 2012

\begin{tabular}{|c|c|}
\hline Treatment & Applications \\
\hline $\begin{array}{l}\text { Treatment I- } \\
\text { Understory clearing } \\
\text { only (T1) }\end{array}$ & $\begin{array}{l}\text { The understory trees or unwanted trees were chosen to be cut. All herbaceous species and saplings of pioneer } \\
\text { species were cleared along the planting line within a radius of } 2 \mathrm{~m} \text { from the planted trees by manual clearing } \\
\text { using a bush knife. The understory clearing was done annually. The width of the cleared area is shown in } \\
\text { Figure } 2 \text {. }\end{array}$ \\
\hline $\begin{array}{l}\text { Treatment II- } \\
\text { Understory clearing }+ \\
\text { selective girdling } \\
\text { (T2) }\end{array}$ & $\begin{array}{l}\text { Understory clearing practices were applied as in T1. Selective girdling was performed only once at the initial } \\
\text { stage of the experiment. A single-blade knife was used to girdle the tree. A ring of the bark all the way around } \\
\text { the trunk was removed. The girdling removed the bark of the encircled trunk to a depth of at least } 1 / 2 \text { inch on } \\
\text { small trees and } 1 \text { to } 11 / 2 \text { inch on larger trees. Girdling was only applied to the most dominant pioneer species } \\
\text { with DBH more than } 10 \mathrm{~cm} \text { and large crown cover. Girdling was performed once at the initial stage of this } \\
\text { study. }\end{array}$ \\
\hline
\end{tabular}

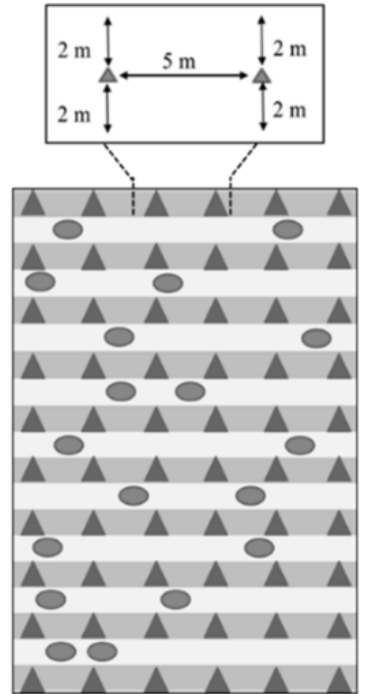

A

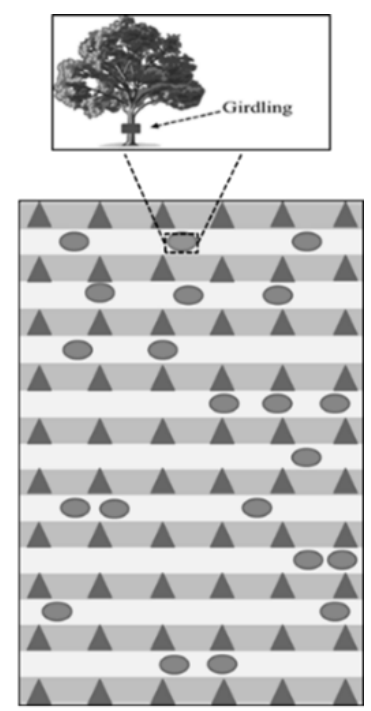

B
Figure 2. Experimental plots and planting layout. A. Treatment 1Understory clearing only (T1), B. Understory clearing plus selective girdling (T2). Note: $\triangle$ : Planted Dryobalanops beccarii. $\bigcirc$ : Pioneer species. $\square$ : Undisturbed planting zone. $\square$ : Tree panting area maintained by understory clearing

Moreover, these two study site was purposely being selected due to almost mutual stand density characteristic in which both considered as mixed dipterocarp forest where predominantly covered by pioneer species mostly Macaranga species. The experimental layout is presented in Figure 2, and the description of the silvicultural practices is shown in Table 1.

\section{Assessment of the growth performance of planted trees}

The monitoring of the growth performance and survival of planted D. beccarii was carried out from 2012 until 2019. For the assessment of the growth performance in the study plots, measurements such as tree diameter at breast height (DBH) and total tree height were assessed annually. The DBH of the trees was measured at a constant height of $1.3 \mathrm{~m}$ above the ground. The height of the tree was measured using a clinometer, and trigonometry was used to determine the tree height. The mean annual increment in diameter (MaiD) and mean annual increment in height (MaiH) were recorded. For all the mean annual increments were calculated using the following formula:

$$
\text { Mean annual increment }=\frac{\text { Final measurement at time }}{\text { Years after planting }}
$$

Relative light intensity in the studied sites was recorded, under standardized conditions as described by Jaffar et al. (2018) using an Extech 401025 Digital Light Meter [Lux/Foot-Candle (FC)] meters. Open space light intensity was measured outside the reforestation sites in order to compare the light intensity under every single tree at the planted area with the open space area. The unit of Foot-Candle was converted into Microeinstein to obtain light percentage according to the formula below (Hattori et al. 2009):

$$
\mathrm{P}=\frac{\mathrm{Q}(\mathrm{FC} \times 0.2)}{\mathrm{R}} \times 100
$$

$\mathrm{P}$ is percentage of light intensity under each tree

$\mathrm{Q}$ is light intensity in Foot-Candle (FC)

$\mathrm{R}$ is open space light intensity

FC $\mathrm{x} 0.2$ is used to convert Foot-Candle unit to Microeinstein

Vegetation survey was carried out in each study plot to determine the number and size for pioneer tree species with the $\mathrm{DBH}$ of more than $10 \mathrm{~cm}$. All recorded species were identified with their scientific names at Universiti Malaysia Sarawak's Herbarium.

\section{Statistical analyses}

The planted tree growth performance in both treatments, including the $\mathrm{DBH}$, height, MaiD, and $\mathrm{MaiH}$, were analyzed using independent Student's t-tests at a 5\% confidence interval. Next, as the independent variables were not distributed normally, nonparametric tests of significance were utilized. The Mann-Whitney U test was used to assess differences in the growth performance data between $\mathrm{T} 1$ and $\mathrm{T} 2$ for each assessment in terms of $\mathrm{DBH}$ and height. All data were analyzed using SPSS version 21.0, and descriptive statistics were generated using Minitab version 18.0. 


\section{RESULTS AND DISCUSSION}

\section{The effect of silvicultural treatments on neighboring pioneer species}

Table 2 shows ten (10) of the most encountered nonplanted or pioneer tree species found in both $\mathrm{T} 1$ and $\mathrm{T} 2$ plots initially and at the 72-month assessment in the experimental plots. As shown in Table 2, Macaranga gigantea was selected to be girdled, as it was the most dominant pioneer tree during the initial assessment of the trial plots. The dominance of $M$. gigantea may be due to the experimental plot being established in secondary forests, as Zakaria et al. (2008) reported that the genus Macaranga prefers to grow in non-forested areas or semiforested areas (secondary forests). In addition, some researchers also reported that stands of $M$. gigantea were commonly found in open areas (Whitmore 1998). It is also generally known as one of the major species dominating secondary forests that are affected by logging activities (Tagawa 1988; Wermer 1997). In addition, most Macaranga species have large lobed leaves that form the main canopy where the characteristic structure and density may allow the development of a dense sub-canopy layer with opaque leaf foliage that will potentially inhibit the light availability for the lower understory and seedlings (Slik et al. 2000). In this trial plot, $36 \mathrm{M}$. gigantea were counted in the initial assessment, and 18 of those with the largest either diameter or canopy crown cover were selected. Later, girdling was performed on these trees. Seventy-two months after the girdling treatment, only 15 trees had fallen naturally, while another 3 trees were still standing but had no visible fresh leaves.

Figure 3 shows the trends in the occurrence of the neighboring pioneer tree species with $\mathrm{DBH}$ more than 10 $\mathrm{cm}$ for both treatments at the initial stage and at 72 months of experimental silviculture implementation. During the initial assessment, the number of pioneer species was higher in the T2 plot than in the T1 plot. This may be ascribed to the dominant occurrence of $M$. gigantea trees in the T2 plot, as shown in Table 2, which would contribute to the pattern of occurrences in the encountered pioneer trees. Meanwhile, after 72 months, the pattern of occurrences changed drastically. The trend shows an increase in the occurrences of larger pioneer species with DBHs greater than $20 \mathrm{~cm}$ in the $\mathrm{T} 1$ plot compared to the percentage occurrences at the initial assessment. Conversely, in the T2 plot, the percentage of pioneer species with DBHs greater than $20 \mathrm{~cm}$ decreased. Thus, the trend of occurrences, as shown in Figure 2, indicates that the number of larger pioneer species in the $\mathrm{T} 1$ plot increased after 72 months compared to that in the $\mathrm{T} 2$ plot. This may be due to the ungirded pioneer species in $\mathrm{T} 1$ inducing the emergence of new saplings inside the study plot.

\section{Survival rate of planted $D$. beccarii in $\mathrm{T} 1$ and $\mathrm{T} 2$}

Figure 4 shows the survival trends of the planted $D$. beccarii for each subsequent month during the duration of this study. In both treatments, the survival rate for planted trees after 36 months was $100 \%$. Later, the survival rate of planted trees in $\mathrm{T} 2$ decreased to $84.9 \%$, while no changes were observed in the survival rate in T1. At 48 and 60 months, the survival percentage in the T2 plot was sustained at $81.1 \%$, with a slight decrease to $79.2 \%$ at 72 months. A slight decrease in survival is normal in secondary forests, as the mortality rate will keep increasing throughout the succession stage until only the fittest planted tree survives. In contrast to $\mathrm{T} 2$, the survival rate in T1 started to decrease gradually at 48 months, and a sudden decrease in the survival rate to $82.9 \%$ was observed at 72 months after silviculture implementation.

In our field observations (Figure 5) during the monitoring process, we noted that the girdled trees had started to die. Some of them may have fallen directly onto planted trees, based on stump observations (Figure 5.A), and damaged the planted trees. Moreover, some of the pioneer species, mainly the Macaranga species in the T1 plot, fell naturally, and their impact affected the overall survival rate of the planted trees (Figure 5.B).

Davies (2001) also reported Macaranga mortality rates in secondary forests of up to $21 \%$, with particularly high mortality among common species such as Macaranga triloba (20.6\%), Macaranga beccariana (17.9\%) and Macaranga winkleri $(16.7 \%)$. Despite the sudden increase in the mortality rates of both plots, the overall survival was still higher than those of some other planting experiments reported from line planting (Ådjers et al. 1995) and gap planting (Otsamo 2000) in Borneo. Otsamo (2000) reported only $71 \%$ survival among Shorea parvifolia after 19 months, while Ådjers et al. (1995) found survival rates between 40-85\% for Shorea johorensis, Shorea leprosula, and Shorea parvifolia after 2 years of planting. Overall, the present study indicated that after 72 months of treatment implementation, both plots showed high survivability of more than $70 \%$.

Table 2. Non-planted tree species encountered in plots planted with Dryobalanops beccarii at the initial assessment and 72 months after silvicultural treatment

\begin{tabular}{lcc} 
Tree species & $\begin{array}{c}\text { No. } \\
\text { encountered } \\
\text { initially }\end{array}$ & $\begin{array}{c}\text { No. } \\
\text { encountered } \\
\text { at 72 months }\end{array}$ \\
\hline T1: Understory clearing only & \multicolumn{2}{c}{ T1 } \\
Macaranga gigantea & 16 & 30 \\
Ficus aurata & 3 & 9 \\
Euodia sp & - & 5 \\
Dactylocladus stenostachys & 4 & 11 \\
Endospermum diadenum & 1 & 7 \\
Horsfieldia sp. & - & 4 \\
Calophyllum sp. & 4 & 6 \\
Litsea sp. & 5 & 5 \\
Lithocarpus sp. & 2 & 3 \\
Artocarpus elasticus & - & 3 \\
T2: Selective girdling + understory clearing & \\
Macaranga gigantea & 36 & 39 \\
Ficus aurata & 18 & 9 \\
Callicarpa sp. & 12 & 2 \\
Ficus auriculata & 4 & 2 \\
Euodia sp. & 4 & 3 \\
Sterculia sp. & 2 & 1 \\
Artocarpus kemando & 2 & 1 \\
Aglaia sp. & 2 & 1 \\
Horsfieldia sp. & 1 & 7 \\
Endospermum diadenum & 1 & 1 \\
& &
\end{tabular}




\section{Growth performance of $D$. beccarii in T1 and T2}

Figure 6 shows the box plot of the distribution of the DBH and height of $D$. beccarii from the initial period until 72 months after silvicultural treatment implementation. Overall, both treatments showed increments in terms of DBH and height. There was no significant difference between the treatments in DBH at the initial stage. However, the tree DBH began to show a significant difference between T1 and T2 at 48 months. Moreover, from the quartile division of the box plot, $\mathrm{T} 2$ showed better growth performance than $\mathrm{T} 1$ in terms of DBH, and most of the DBH was tabulated in quartile 3. In terms of tree height, the planted trees in both treatments showed no significant difference at the initial assessment. Then, from 24 months onward, there were significant differences in tree height between the treatments. However, both treatments showed variation in the quartile divisions for each assessment, resulting in difficulties in determining which treatments contributed more to tree height. However,
T2 showed greater growth performance in height than T1, even though there were no immediate effects on height.

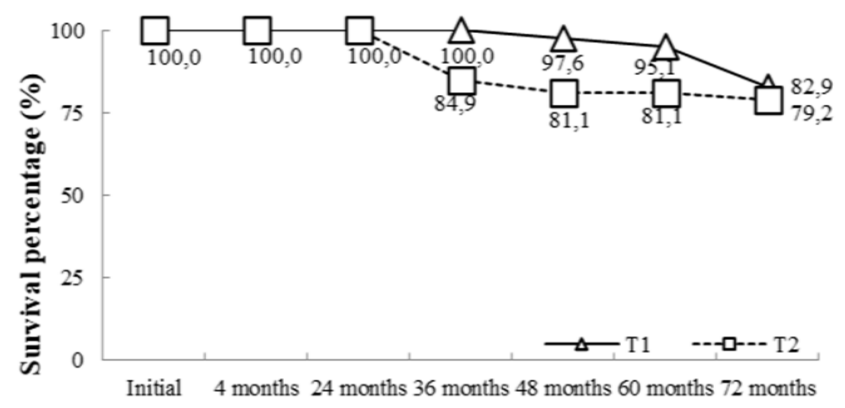

Figure 4. Survival of planted Dryobalanops beccarii for both treatments

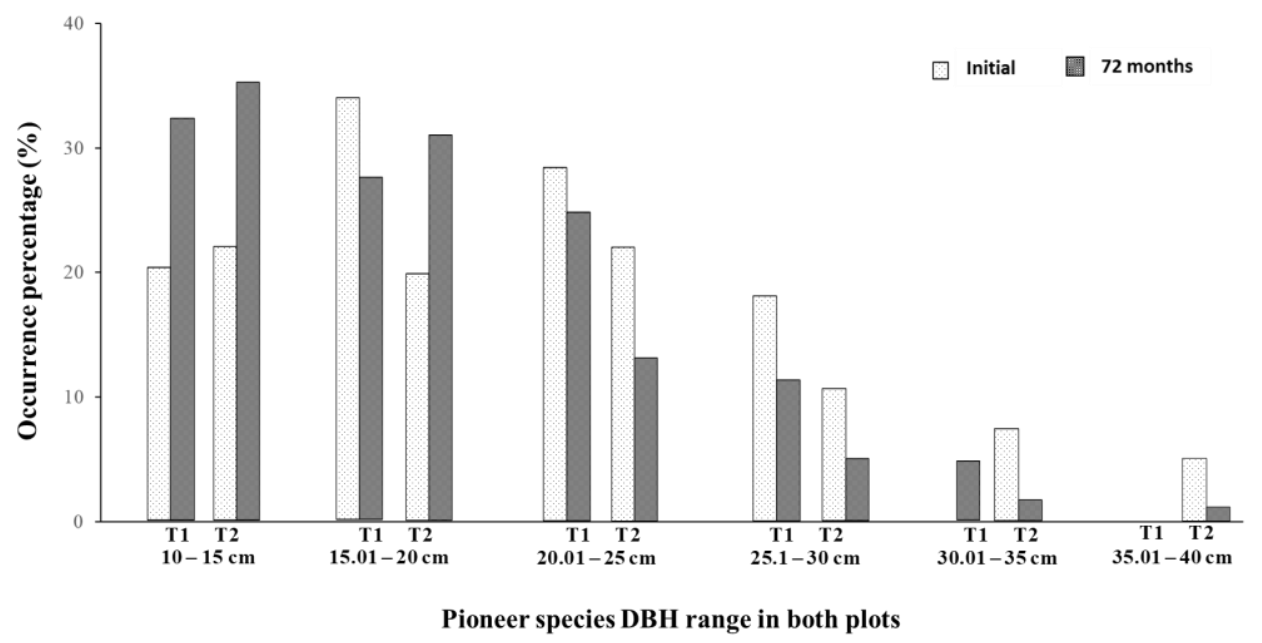

Figure 3. Occurrence percentage of pioneer species with $\mathrm{DBH}<10 \mathrm{~cm}$ at initial silviculture implementation and after a period of 72 months
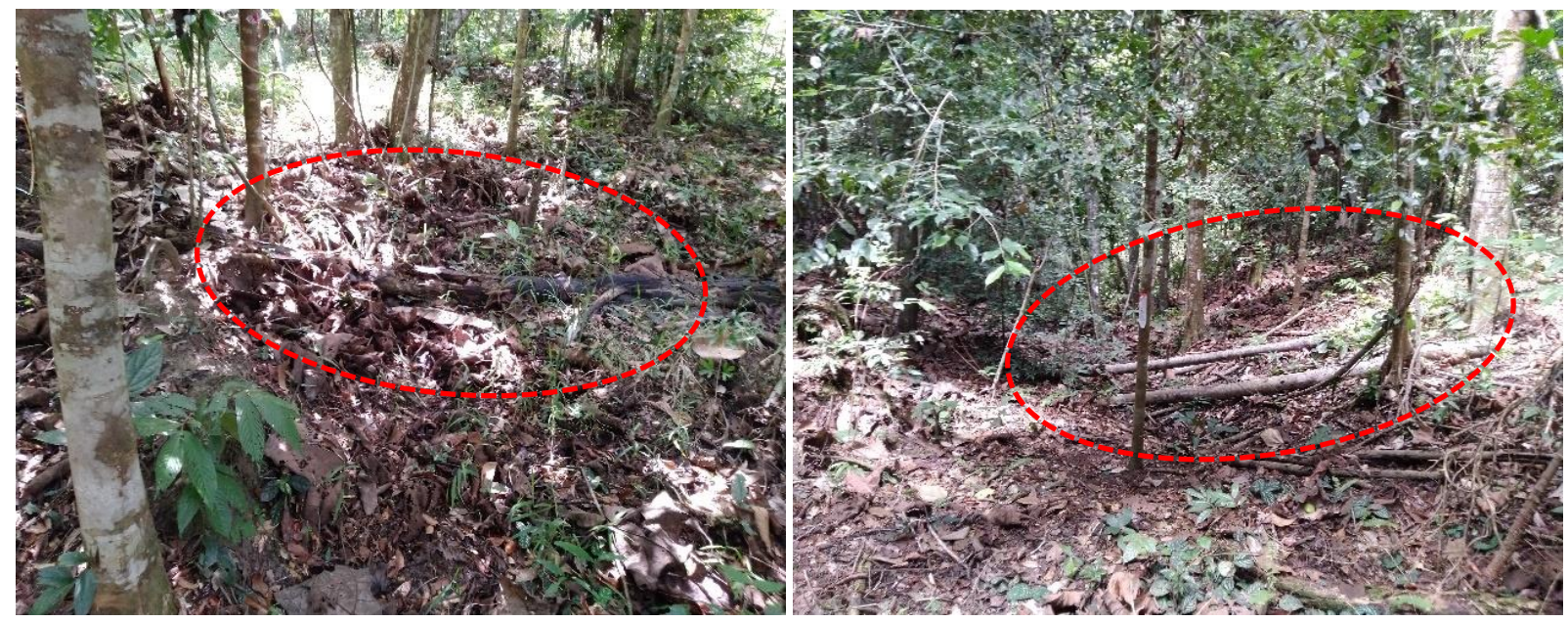

Figure 5.A. Fallen, fully rotten girdled tree in T2, B. Naturally fallen Macaranga gigantea that induced mortality in T1 

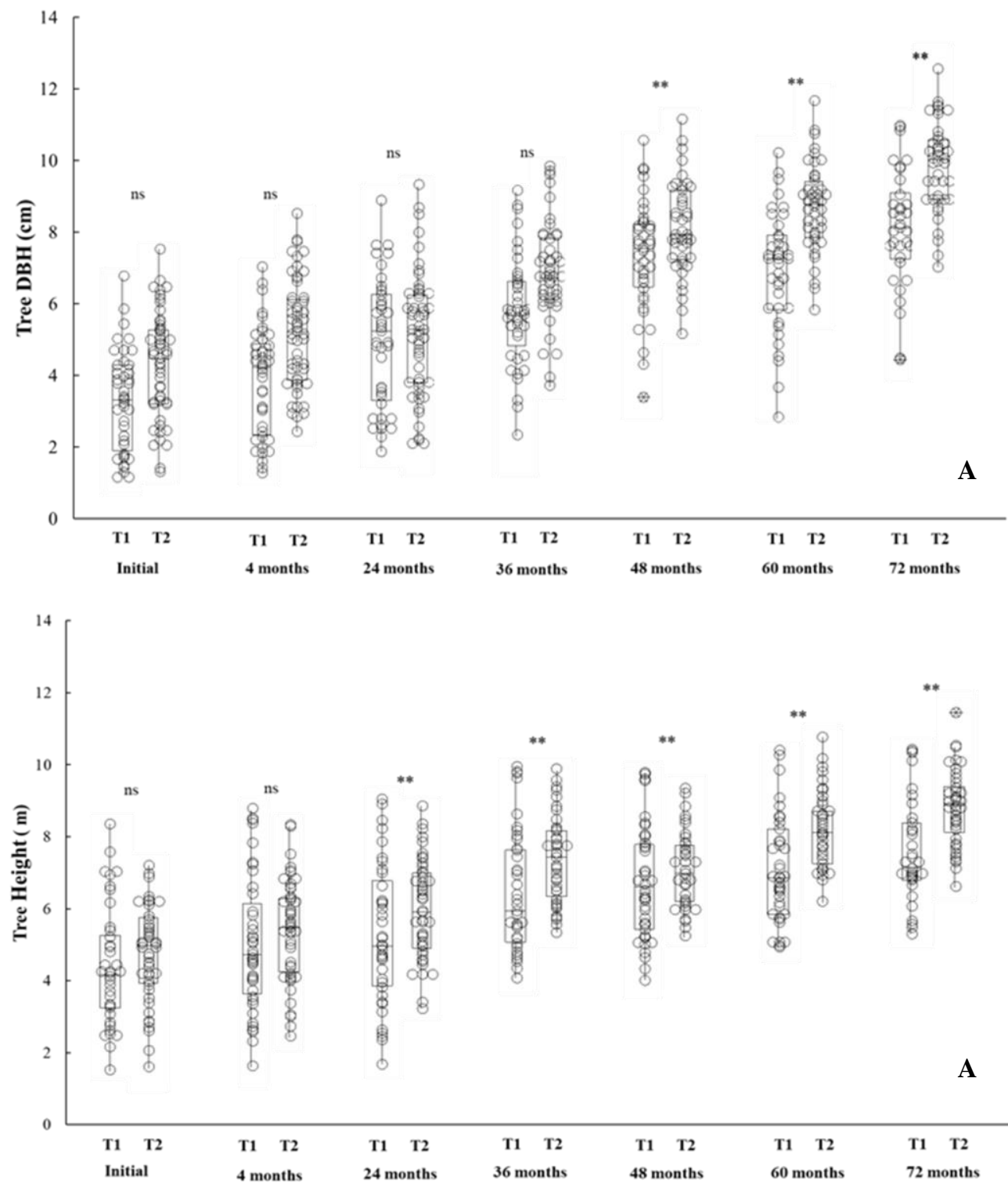

Figure 6. Boxplot distribution of the growth performance of planted Dryobalanops beccarii for both treatments. A. Mean annual increment in diameter, B. Mean annual increment in height. ** indicates a significant difference between both treatments using an independent Student's t-test at 5\%. ns: not significant

The mean annual increments in DBH and height of the planted D. beccarii under treatments $\mathrm{T} 1$ and $\mathrm{T} 2$ are shown in Table 3 and expressed in $\mathrm{cm}$ year- ${ }^{1}$ and $\mathrm{m} \mathrm{year}^{-1}$ for DBH and height, respectively. Initially, the growth rates in $\mathrm{DBH}$ for $\mathrm{T} 1$ and $\mathrm{T} 2$ were 0.43 and $0.53 \mathrm{~cm} \mathrm{year}{ }^{-1}$, respectively, and statistical analysis using the t-test showed no significant difference among the treatments initially. In addition, in terms of the growth rate in height, there was no significant difference between $\mathrm{T} 1$ and $\mathrm{T} 2$, and the rates were 0.55 and $0.64 \mathrm{~m} \mathrm{year}^{-1}$, respectively. Then, at 24 months, T2 started to show a higher growth rate in height compared to T1. Next, Table 3 also shows the comparative statistics between T1 and T2 using the Mann-Whitney U test to further investigate which treatments contribute more to the growth performance of planted trees. The findings indicated that there are significant differences between treatments $\mathrm{T} 1$ and $\mathrm{T} 2$ for each particular assessment, i.e., growth in terms of height or diameter. From the P-value, T2 shows significantly higher growth performance in diameter than T1 ( $\mathrm{P}<0.001)$. Meanwhile, for the height parameter, the findings showed variation in the P-value, where $0.01<\mathrm{P}<0.1$. This suggests that the T2 plot, where the implementation of selective girdling was accompanied by undergrown slashing, contributed more to the growth performance of the planted $D$. beccarii than T1, which did not have girdling practices. 
Table 3. Results of the t-test and nonparametric test (Mann-Whitney U test) for the mean annual increment in diameter (MaiD) and height (MaiH) of planted Dryobalanops beccarii at T1 and T2

\begin{tabular}{|c|c|c|c|c|c|}
\hline \multirow{2}{*}{\multicolumn{2}{|c|}{ Parameter }} & \multirow{3}{*}{$\begin{array}{c}\begin{array}{c}\text { Stand age } \\
\text { (year) }\end{array} \\
8\end{array}$} & \multicolumn{2}{|c|}{ Treatment } & \multirow{2}{*}{$\begin{array}{c}\text { Mann-Whitney test } \\
\text { P-value }\end{array}$} \\
\hline & & & T1 & $\mathbf{T 2}$ & \\
\hline \multirow{7}{*}{$\begin{array}{l}\text { Mean annual increment in } \\
\text { diameter }\end{array}$} & Initial & & $0.43 \pm 0.21 \mathrm{~ns}$ & $0.53 \pm 0.22 \mathrm{~ns}$ & $0.026^{*}$ \\
\hline & 4 months & 9 & $0.44 \pm 0.20 \mathrm{~ns}$ & $0.52 \pm 0.20 \mathrm{~ns}$ & 0.096 \\
\hline & 24 months & 11 & $0.42 \pm 0.20 \mathrm{~ns}$ & $0.52 \pm 0.19 \mathrm{~ns}$ & $0.021 *$ \\
\hline & 36 months & 12 & $0.48 \pm 0.15 a$ & $0.62 \pm 0.14 b$ & $0.000 * * *$ \\
\hline & 48 months & 13 & $0.51 \pm 0.14 \mathrm{a}$ & $0.66 \pm 0.11 b$ & $0.000 * * *$ \\
\hline & 60 months & 14 & $0.50 \pm 0.14 \mathrm{a}$ & $0.64 \pm 0.11 b$ & $0.000 * * *$ \\
\hline & 72 months & 15 & $0.50 \pm 0.13 \mathrm{a}$ & $0.63 \pm 0.10 b$ & $0.000 * * *$ \\
\hline \multirow{7}{*}{$\begin{array}{l}\text { Mean annual increment in } \\
\text { height }\end{array}$} & Initial & 8 & $0.55 \pm 0.25 \mathrm{~ns}$ & $0.64 \pm 0.20 \mathrm{~ns}$ & $0.034 *$ \\
\hline & 4 months & 9 & $0.59 \pm 0.26 \mathrm{~ns}$ & $0.65 \pm 0.19 \mathrm{~ns}$ & 0.095 \\
\hline & 24 months & 11 & $0.54 \pm 0.22 \mathrm{a}$ & $0.61 \pm 0.15 b$ & 0.074 \\
\hline & 36 months & 12 & $0.55 \pm 0.18 \mathrm{a}$ & $0.63 \pm 0.12 b$ & $0.024 *$ \\
\hline & 48 months & 13 & $0.56 \pm 0.15 a$ & $0.63 \pm 0.10 b$ & $0.014 *$ \\
\hline & 60 months & 14 & $0.55 \pm 0.14 \mathrm{a}$ & $0.62 \pm 0.09 b$ & $0.004 * *$ \\
\hline & 72 months & 15 & $0.55 \pm 0.12 \mathrm{a}$ & $0.61 \pm 0.09 b$ & $0.009 * *$ \\
\hline
\end{tabular}

Notes: Different letters indicate significant differences at 5\% using an independent Student's t-test between $\mathrm{T} 1$ and $\mathrm{T} 2$, ns $=$ no significance, Mann-Whitney nonparametric test-*p<0.05, **p $<0.01$ and $* * * \mathrm{p}<0.001$

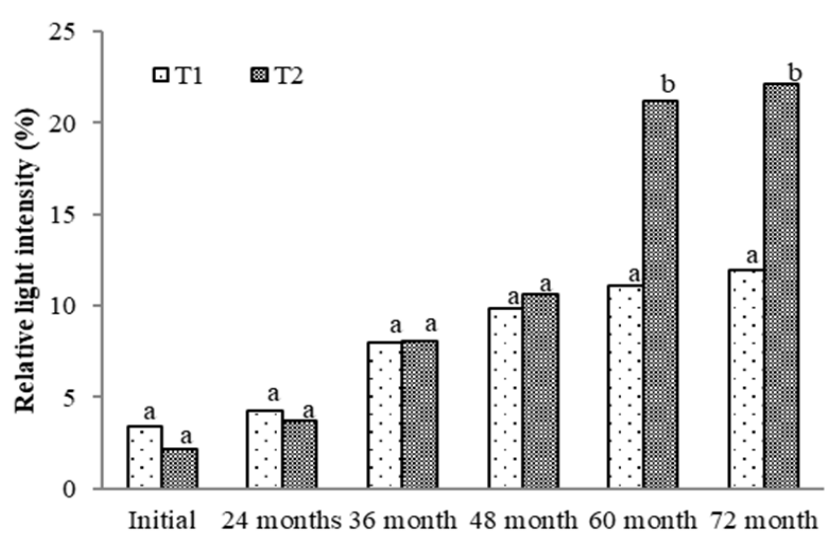

Figure 7. Relative light intensity trend over 72 months of silviculture implementation. Different letters indicate significant differences at $5 \%$ using an independent Student's t-test

\section{Influence of selective girdling as an additional silviculture treatment on the RLI at the forest floor}

Figure 7 shows the relative light intensity (RLI) for each particular assessment. At initial, the RLI at both plots showed no significant differences. The RLI gradually increase for both treatments throughout the monitoring period. At 60 months, RLI in T2 was significantly higher as compared to T1. Based on our field observation, the girdled M. gigantea in $\mathrm{T} 2$ has fallen onto the forest floor creating a significant forest gap. Romell (2007) explained that girdling practice was more persistent over time as compared to other canopy opening treatments. Besides, increasing the light intensity in the forest floor will lead to better growth performance of the target trees as Brown (1993) and Hattori et al. (2013) suggested that sunlight exposure in a secondary forest can enhance the growth performance of Dipterocarp species.

\section{Discussion}

Girdling does not instantly fell or decompose unwanted trees, as this practice inhibits nutrient uptake by the targeted tree and results in the defoliation and slow death of the girdled tree. However, the application of selective girdling crucial in this study to reduce the dominancy of $M$. gigantea in the study plot as this pioneer species can inhibit or suppressed the growth performance of the planted tree. Aoyagi et al. (2012) reported that the presence of Macaranga patches can affect the performance of dipterocarp seedlings through forest floor conditions because the nutrient accumulation rate beneath the litter layers is slow, resulting in the slow recovery of the nutrient availability of the forest floor. Hence, the immediate defoliation of the Macaranga tree by girdling reduces the possibility of slow nutrient recovery since the defoliated leaves degrade faster than naturally fallen fresh leaves. In the T1 plot, where no girdling was applied, the number of $M$. gigantea increased 72 months after the beginning of this study. Moreover, controlling the emergence of pioneers with a dense canopy layer is important for improving the light conditions on the forest floor, as light intensity was the main factor influencing seedling mortality and growth during the first 24 months of planting (Hattori et al. 2009).

Removing the pioneer species via girdling gradually increases the light intensity, as girdling practices do not provide a direct increase in light availability on the forest floor. Gradually increasing the light intensity provides optimum conditions for the planted $D$. beccarii. This species is considered a shade-tolerant tree at the seedling stage, and overexposure to sunlight causes scorching on the leaves. Incorporating the selective girdling of the dominant 
Macaranga trees in the experimental plot allows the girdled trees to die slowly and reduces their impact when they fall, which provides a more favorable environment for the planted seedling. Furthermore, a decrease in stand density to an intermediate level can enhance the growth rate of seedlings planted under the trees (Paquette et al. 2006). There were some increases in the number of other pioneer trees (Table 2), such as Ficus aurata, Dactylocladus stenostachys, Lithocarpus sp. and Horsfieldia sp., in the study plot 72 months after silviculture implementation. This is considered a normal phenomenon in the secondary forest, where the number of plant species rises during the young secondary regrowth phase (Wermer 1997). Moreover, pioneer species proliferated shortly after silvicultural interventions but then diminished to primary forest levels by 20 to 30 years of post-treatment (Phillips et al. 2003; Van Gardingen et al. 2003).

In addition, girdling practices accompanied by slashing is also important to consider, since slashing frees the naturally growing or planted tree species from competition (Carandang et al. 2007). Overall, the growth rate was still higher than that of naturally grown seedlings; Widiyatno et al. (2013) reported that in natural tropical rainforests, the total growth rate for all species was approximately $0.22 \mathrm{~cm}$ year $^{-1}$, while for dipterocarp species, it was within the range of $0.34-0.40 \mathrm{~cm}$ year $^{-1}$. The girdling practices provide a competitive advantage for shade-tolerant species over pioneer forest floor vegetation, thus allowing the planted seedlings to gradually gain control of the growth resources liberated in the gap and prolonging the effect of the girdling (Romell et al. 2008). In addition, planting gaps created by girdling and slashing favored shade-tolerant dipterocarp species over light-demanding species (e.g., Macaranga sp.) due to the low level of irradiance in the sub-canopy layer (Sovu et al. 2010).

The results obtained from multiple assessments in the plots treated with different silvicultural treatments showed that girdling practices had a positive effect on the growth performance of the $D$. beccarii planted for reforestation purposes in GANP. The practice of girdling has a slow effect. The girdled pioneer tree does not die immediately, as it would in felling practices, because girdling practices do not lead to the immediate death and defoliation of the girdled tree. The effects of girdling are more difficult to assess than those of other practices, such as thinning and felling, in which the treated tree falls immediately. However, the effects of girdling are more persistent over time, and less damage is induced to the planted trees. This can be seen in Table 3; the girdling plot (T2) started to show better growth in diameter and height at 36 months and 24 months, respectively. Thus, the practice of selective girdling of pioneer species starts to take effect after 24 months, when the girdled tree starts to fall and provides favorable light conditions for the planted trees to grow. Romell (2007) reported that selective girdling needs at least 2 years after implementation to see its effects on canopy opening and the light environment on the forest floor. One possible explanation for the better height growth rate in the T2 plot was that the girdled trees had fallen, creating more favorable light conditions for the planted trees to grow taller. The slower growth performance in T1 may be due to the low light conditions releasing shade-tolerant pioneer vegetation and obstructing the establishment of slowgrowing tree seedlings (Romell et al. 2008). Next, the Mann-Whitney test showed that the trees planted in the T2 plot showed better growth performance than those in T1, and the mean annual increments in diameter and height were significantly higher than those in the T1 plot at 36 months onwards. The P-value in Table 3 shows that the MAI in diameter was strongly significant at $p<0.001$ and was an important indicator, as the increment in diameter indicated that the planted tree started to increase greatly in size. Although this effect was only seen after 36 months, which is slower than 6-12 months, as reported by some researchers, there is great variability in the ecosystem, as various edaphic factors can obstruct the slow growth of the planted indigenous tree species.

For rehabilitation purposes, the speed of tree growth in planted indigenous trees is crucial, but tree survival after anthropogenic activities is another main consideration. In terms of survival rate, T2 showed a better growth pattern than T1. In T2, the survival rate was almost stable with no sudden increase in mortality rate. In T1, a sudden mortality increase was observed 60 months after the implementation of silvicultural treatment. Overall, both treatments T1 and T2 were practicable for managing the planted $D$. beccarii trees in GANP and could increase the probability for the tree to grow and adapt well to the ecosystem. However, the $\mathrm{T} 2$ practices were preferable because they tend to provide a better environment for planted indigenous trees to grow. In addition, T2 showed slightly faster growth in MaiD and MaiH than T1, with averages of $0.63 \mathrm{~cm}_{\text {year }}{ }^{-1}$ and $0.61 \mathrm{~m}$ year $^{-1}$, respectively, compared to $\mathrm{T} 1$, with averages of 0.50 $\mathrm{cm}$ year $^{-1}$ and $0.55 \mathrm{~m}$ year ${ }^{-1}$, respectively. The canopy openings created by girdling and the gaps created by slashing in T2 provided optimum growth conditions for $D$. beccarii. In addition, light availability plays an important role in regenerating tropical tree seedlings (Agyeman 1994). Creating gaps by slashing the understory seems to be an efficient treatment for forest floor shade reduction in secondary tropical forests (Romell et al. 2009). Mauricio (1987) also reported that dipterocarp seedlings or stands with $\mathrm{DBH}$ values ranging from $5-20 \mathrm{~cm}$ will triple their growth when competing for secondary growth is cleared. As in this study, girdling was only applied when the stands were eight (8) years old, since most dipterocarps seedlings demand shelter from sunlight during their establishment phase (Nicholson 1960; Weidelt and Banaag 1982; Mauricio 1987). Moreover, young trees (less than $30 \mathrm{~cm}$ in $\mathrm{DBH}$ ) react better to liberation and a subsequent increase in light intensity (Weidelt and Banaag 1982). Aside from canopy treatments (girdling), weeding or slashing practices are also essential; at a young age, dipterocarp trees need intensive tending (Ådjers et al. 1995). The frequency of slashing also has to be adjusted considering the main climatic conditions in the area (Carandang et al. 2007). The study plot is located in a tropical rainforest, where weeds emerge rapidly due to the availability of rainfall throughout the year. Therefore, the frequency of slashing should be 
high, and slashing should be conducted at a constant interval; if weeding is carried out inconsistently, the dipterocarps will be easily damaged (Priasukmana 1991). Although some forest plantation management systems primarily practice felling rather than frequent slashing due to the cost of maintenance, Weidelt (1976) pointed out the importance of maintenance, as insufficient tending is the most common reason for failure.

For the purposes of reforestation, and as recommended by Wasli et al. (2014) in their preliminary assessment, suitable silvicultural practices should be applied to ensure the success of reforestation programs. In the present study, our findings suggested that additional silvicultural treatment by means of selective girdling could be adopted to enhance the growth performance of planted trees in the reforestation program at GANP. As the forest continues to regenerate, given time and disturbance, the pioneer species in the forest will decline and be replaced by climax species, converting the secondary forest into a forest community that is similar to that of a mature primary forest (Osborne 2012). Hence, the implementation of selective girdling practices is crucial for enhancing the process of forest restoration, since natural primary forests take decades to reach maturity. To ensure successful enrichment planting, the necessary conditions must be met, including the provision of adequate light conditions, proper supervision and follow-up maintenance (especially for canopy opening treatments) (Akindale and Onyekwelu 2011).

Meanwhile, the location of the pioneer tree that will be girdled should be taken into consideration to fully utilize the gap created when the girdled tree falls. In addition, the intensity of the girdling should be taken into consideration to ensure its effective application. Slashing the undergrowth is still recommended, despite its cost, to keep the planting line accessible for future supervision and tending activities (Ådjers 1995). Further comprehensive studies in the future should broaden their focus to examine pioneer species competition with planted trees, soil-plant relationships, and canopy opening through the treatments applied. Meanwhile, the existing natural pioneer species inside the study plot that interact and compete with the planted trees for light, space, and nutrients should be identified clearly in future studies.

\section{ACKNOWLEDGEMENTS}

We wish to express our gratitude to the Director and staff of the Forest Department, Sarawak, Malaysia for their supportive assistance during the duration of this study. This research was financially supported by the research grant from Fundamental Research Grant Scheme (FRGS (E14099/F07/69/989/2013 (30)) and Grant-in-Aid for scientific research purpose by the Japan-Malaysia Association (JMA).

\section{REFERENCES}

Ådjers G, Kuusipalo J, Hadengganan S, Nuryanto K, Vesa L. 1995. Enrichment planting of dipterocarps in logged-over secondary forest, effects of width, direction and maintenance method of planting line on selected Shorea species. For Ecol Manag 73 (1-3): 259-270.

Agyeman VK. 1994. Environmental Influences On Tropical Tree Seedling Growth. [PhD dissertation]. University of Aberdeen, UK.

Akindale SO, Onyekwelu JC. 2011. Silviculture in secondary forests. In: Gunter S, Weber M, Stimm B, Mosandl R (eds), Silviculture In: The Tropics. Springer-Verlag, London.

Aoyagi R, Imai N, Kitayama K. 2012. Ecological significance of the patches dominated by pioneer trees for the regeneration of dipterocarps in a Bornean logged-over secondary forest. For Ecol Manag 289: 378-384.

Appanah S, Weinland G. 1993. Planting Quality Timber Trees in Peninsular Malaysia. Forest Research Institute Malaysia, Kepong.

Ashton PS. 2004. Tree flora of Sabah and Sarawak (Vol. Five). In: Soepadmo E, Saw LG, Chung RKC. (eds). Dipterocarpaceae. Government of Malaysia, Kuala Lumpur.

Brown N. 1993. The implications of climate and gap microclimate for seedling growth conditions in a Bornean lowland rain forest. J Trop Ecol 9 (2): 153-168.

Carandang WM, Paelmo R, Lee DK, Carandang VQ. 2007. Assisted natural regeneration as affected by lodging and slashing vegetation in grassland in the Philippines. For Sci Tech 3 (1): 47-52.

Chai DNP, Udarbe MP. 1977. The effectiveness of current silvicultural practice in Sabah. Malays For 40: 27-35.

Colin TM, Cara RN, Andrew JL, Anna S. 2018. Ecological effects and effectiveness of silvicultural restoration treatments in whitebark pine forests. For Ecol Manag 429: 534-548.

Davies SJ. 2001. Tree mortality and growth in 11 sympatric Macaranga species in Borneo. Ecology 82: 920-932.

Forest Department Sarawak. 2009. Types and Categories of Sarawak Forest. Retrieved on March 13, 2014, from www.forestry.sarawak.gov.my/forweb/outfor/typefor/tcsf.htm

Fredericksen TS, Mostacedo B. 2000. Regeneration of timber species following selection logging in a Bolivian tropical dry forest. For Ecol Manag 131: 47-55.

Fredericksen TS, Putz FE. 2003. Silvicultural intensification for tropical forest conservation. Biodivers Conserv 12: 1445-1453.

Gaveau DLA, Sloan S, Molidena E, Yaen H, Sheil D. 2014. Four decades of forest persistence, clearance, and logging on Borneo. PLoS ONE 9 (7): e101654. DOI: 10.1371/journal.pone.0101654

Graaf NR. 1986. A silvicultural system for natural regeneration of tropical rain forest in Surinam. Landbouwhogeschool, Wageningen.

Hattori D, Kenzo T, Kendawang JJ, Ninomiya I, Sakurai K. 2013. Rehabilitation of degraded Tropical Rainforest using Dipterocarp trees in Sarawak, Malaysia. Intl J For Res 2013 (1): DOI: $10.1155 / 2013 / 683017$

Hattori D, Kenzo T, Kendawang JJ, Irino KO, Tanaka S, Ichie T, Ninomiya I, Sakurai K. 2009. Effect of light intensity and soil physicochemical properties on seedling mortality and growth of six Dipterocarp species planted for rehabilitation of degraded grassland, secondary forest and logged forest of Sarawak, Malaysia. Jpn J For Environ 51 (2): 105-115.

Jackson SM, Fredericksen TS, Malcolm JR. 2002. Area disturbed and residual stand damage following logging in a Bolivian tropical forest. For Ecol Manag 166: 271-283.

Jaffar ANN, Wasli ME, Perumal M, Lat J, Sani H. 2018. Effects of soil compaction and relative light intensity on survival and growth performance of planted Shorea macrophylla (de Vriese) in riparian forest along Kayan Ulu River, Sarawak, Malaysia. Intl J For Res 2018 (2): DOI: $10.1155 / 2018 / 6329295$

Kammesheidt L. 2002. Perspectives on secondary forest management in tropical humid Lowland America. Ambio 31: 243-250.

Kammesheidt L, Dagang AA, Schwarzwäller W, Weidelt HJ. 2003. Growth patterns of dipterocaprs in treated and untreated plots. For Ecol Manage 174: 437-445.

Lamprecht H. 1989. Silviculture in the Tropics. Deutsche Gesellschaft fur Techiche Zusammearbeit (GTZ), Germany.

Lee PS. 2013. Effectiveness of selective girdling in enhancing the growth performance of planted Dryobalanops beccarii under reforestation at Gunung Apeng, FR, Sarawak. [Hon. Thesis]. Universiti Malaysia Sarawak, Malaysia.

Mauricio FP. 1987. Enrichment planting improves logged over Dipterocarp forests: the Philippine experience. In: Kostermans AJGH (ed), Proc. of the $3^{\text {rd }}$ Round-Table Conference on Dipterocarps, MAB, UNESCO, Indonesia. 
McNamara S, Tinh DV, Erskine PD, Lamb D, Yates D, Brown S. 2006 Rehabilitating degraded forestland in central Vietnam with mixed forestland in central Vietnam with mixed native species plantings. For Ecol Manag 233: 358-365.

Nicholson DJ. 1960. Light requirements of seedlings of live species of Dipterocarpaceae. Malays For 23: 344-356.

Nyland RD. 1996. Silviculture. McGraw-Hill, United States of America.

Oliver CD. 1992. Similarities of stand structures and stand development processes throughout the world-dome evidence and applications to silviculture through adaptation management. In: Kelty MJ, Larson BC, Oliver CD (eds.). The Ecology and Silviculture of Mixed-species Forests. Kluwer Academic Publisher, Netherlands.

Osborne PL. 2012. Tropical Ecosystems and Ecological Concepts $\left(2^{\text {nd }}\right.$ ed.). Cambridge University Press, UK.

Otsamo R. 2000. Early development of three planted indigenous tree species and natural understorey vegetation in artificial gaps in an Acacia mangium stand on an Imperata cylindrica grassland site in South Kalimantan, Indonesia. New For 19: 51-68.

Paquette A, Bouchard A, Cogliastro A. 2006. Survival and growth of under-planted trees: a meta-analysis across four biomes. Ecol Appl 16: 1575-1589.

Perumal M, Wasli ME, Ho SY, Lat J, Sani H. 2017. Survivorship and growth performance of Shorea macrophylla (de Vriese) after enrichment planting for reforestation purposes at Sarawak, Malaysia. Online J Biol Sci 17 (1): 7-17.

Phillips P, Brash T, Yasman I. 2003. An individual-based spatially explicit tree growth model for forests in East Kalimantan (Indonesian Borneo). Ecol Modell 159: 1-26.

Priasukmana S. 1991. Planting experiments of dipterocarps in East Kalimantan. In: Soerianegara I, Tjitrosomo SS, LJmaly RC, LJmboh I (eds). Proceeding of the $4^{\text {th }}$ Round-Table Conference on Dipterocarps, Riotrop Special Publication No. 41, Bogor. Indonesia.

Ramos JM, del Amo S. 1992. Enrichment planting in a tropical secondary forest in Veracruz, Mexico. For Ecol Manag 54: 289-304.

Romell E. 2007. Artificial canopy gaps and the establishment of planted dipterocarp seedlings in Macaranga spp.-dominated secondary tropical rain forests of Sabah, Borneo. [Dissertation] Swedish University of Agricultural Sciences, Uppsala.

Romell E, Hallsby G, Karlsson A. 2009. Forest floor light conditions in a secondary tropical rain forest after artificial gap creation in northern Borneo. Agric For Meteorol 149: 929-937.

Romell E, Hallsby G, Karlsson A, Garcia C. 2008. Artificial canopy gaps in a Macaranga spp. dominated secondary tropical rain forest-effects on survival and above ground increment of four under-planted dipterocarp species. For Ecol Manag 255: 1452-1460.
Slik JWF, Priyono, van Welzen PC. 2000. Key to the Macaranga and Mallotus species (Euphorbiaceae) of East Kalimantan, Indonesia. Gard Bull Singap 52: 11-87.

Sovu, Tigabu M, Savadogo P, Odén PC. 2010. Enrichment planting in a logged-over tropical mixed deciduous forest of Laos. J For Res 21 (3): 273-280.

Tagawa, H. 1988. Change of Vegetation in Kutai National Park, East Kalimantan. Kagoshima University Research Centre for the South Pacific, Japan.

Van Gardingen PR, McLeish M, Phillips PD, Fadilah D. Tyrie G, Yasman I. 2003. Financial and ecological analysis of management options for logged-over dipterocarp forests in Indonesian Borneo. For Ecol Manag 183: 1-29.

Villages Z, Pena-Claros M, Mostacedo B, Alarcon A, Licona JC, Leano C, Pariona W, Choque U. 2009. Silvicultural treatments enhance growth rates of future crop tress in a tropical dry forest. For Ecol Manag 258: 971-977.

Wasli ME, Sani H, Ho SY, Perumal M, Zainuddin ZA, Lat J, Lee PS. 2014. Preliminary assessment on the growth performance of Dryobalanops beccarii Dyer planted under enrichment planting technique at Gunung Apeng Forest Reserve, Sarawak, Malaysia. Kuroshio Sci 8 (1): 45-52.

Weidelt HJ. 1976. Improvement of over logged areas by enrichment planting. In: Weidelt HJ (ed), Manual of Reforestation and Erosion Control for the Philippines. GTZ, Eschborn, Germany.

Weidelt HJ, Banaag VS. 1982. Aspects of management and silviculture of Philippine dipterocarp forest. GTZ Eschborn Publ. No. 132, Germany.

Wermer S. 1997. The impact of management practices on species richness within productive rubber agroforestry in Indonesia. In: Sist P, Sabogal C, Byron Y (eds), Management of Secondary and Logged-Over Forests in Indonesia; Selected Proceedings of an International Workshop. Center for International Forestry Research, Bogor, 17-19 November 1997.

Whitmore TC. 1998. An Introduction to Tropical Rainforest. $2^{\text {nd }}$ ed.. Oxford University Press, Clarendon, Oxford.

Widiyatno, Nai'em, Moh, Kanzaki M, Purnomo S, Jatmoko. 2013. Application of silviculture treatment to Support Rehabilitation on Logged Over Area (LOA) of Tropical Rainforest, Central Kalimantan, Indonesia. J Sustain 1 (2): 50-55.

Wyatt-Smith J. 1963. Manual of Malayan Silviculture for Inland Forests. Vol (23), Malayan Forest Records. Kuala Lumpur, Malaysia.

Zakaria R, Nik FNR, Mansor M, Zakaria MY. 2008. The distribution of Macaranga, genus (family Euphorbiaceae) in Penang Island, Peninsular Malaysia. J Biosci 19 (2): 91-99. 